\title{
Short Communication: Inactivation of Microbial Contaminants in Raw Milk La Serena Cheese by High-Pressure Treatments
}

\author{
J. L. Arqués, S. Garde, P. Gaya, M. Medina, and M. Nuñez ${ }^{1}$ \\ Departamento de Tecnología de Alimentos, INIA, Carretera de La Coruña Km 7, Madrid, 28040 Spain
}

\section{ABSTRACT}

La Serena cheese, a Spanish variety made from Merino ewes' raw milk, has a high $\mathrm{pH}$ value, low salt content, and high moisture, conditions that are all favorable for growth and survival of contaminating microorganisms, including pathogens. To improve its microbiological quality and safety, high-pressure treatments at 300 or $400 \mathrm{MPa}$ for $10 \mathrm{~min}$ at $10^{\circ} \mathrm{C}$ were applied to 2 batches of La Serena cheese on d 2 or 50 of ripening. Cheese treated on d 2 at $300 \mathrm{MPa}$ showed viable aerobic counts that were $0.99 \log$ units lower than those for control cheese on $\mathrm{d} 3$ and showed counts of enterococci, coagulase-positive staphylococci, gram-negative bacteria, and coliforms that were $2.05,0.49,3.14$, and $4.13 \mathrm{log}$ units lower, respectively, than control cheese. For cheese treated on $\mathrm{d} 2$ at $400 \mathrm{MPa}$, the respective reductions in counts were $2.02,2.68,1.45,3.96$, and $5.50 \log$ units. On $\mathrm{d} 60$, viable aerobic counts in cheese treated on $\mathrm{d} 50$ at $300 \mathrm{MPa}$ were $0.50 \log$ units lower than those in control cheese, and counts of enterococci, gram-negative bacteria, and coliforms were 1.37, 2.30, and $4.85 \mathrm{log}$ units lower, respectively. For cheese treated on d 50 at 400 $\mathrm{MPa}$, the respective reductions in counts were $1.29,1.98$, 4.47, and $>5$ log units. High-pressure treatments at 300 or $400 \mathrm{MPa}$ on d 2 or 50 reduced significantly the counts of undesirable microorganisms, improving the microbiological quality and safety of La Serena cheese immediately after treatment and at the end of the ripening period.

Key words: high pressure, microbial contaminant, raw milk cheese, La Serena

Increasing consumer demand for safe but minimally processed foods has stimulated research on nonthermal processing techniques such as high-pressure (HP) treatment. The pressure applied (200 to 1,000 MPa) is instantaneously and uniformly transmitted in the food; it affects adversely the cell wall, cell membrane, and enzymes of microorganisms (Smelt, 1998; Farkas and

Received September 7, 2005.

Accepted October 28, 2005.

${ }^{1}$ Corresponding author: nunez@inia.es
Hoover, 2000), leading to their injury and death. Magnitude of the pressure, treatment time and temperature, microbial species and strain, cell growth phase, and suspending media influence the sensitivity of microorganisms to HP treatment.

High-pressure treatment is a useful tool for the inactivation or reduction of pathogenic and spoilage microorganisms in cheese (O'Reilly et al., 2000; Trujillo et al., 2002). Several studies have shown the efficacy of HP treatment to reduce counts of Escherichia coli O157:H7 (O'Reilly et al., 2000; Rodríguez et al., 2005), Listeria monocytogenes (Carminati et al., 2004; Arqués et al., 2005b), and Staphylococcus aureus (O'Reilly et al., 2000; Arqués et al., 2005a) in different cheese varieties.

La Serena cheese, a semisoft Spanish variety with Designation of Origin, is made in Extremadura (western Spain) from Merino ewes' raw milk, with no added lactic cultures, using an aqueous extract of macerated thistle (Cynara cardunculus) flowers as milk coagulant. The high $\mathrm{pH}$ values of cheese during the first stages of ripening, together with its high moisture and low salt content, are favorable for growth of contaminating microorganisms, including pathogens (Fernández del Pozo et al., 1988; Sánchez-Rey et al., 1993).

In the present study, raw milk La Serena cheeses were treated at 300 or $400 \mathrm{MPa}$ for 10 min on d 2 or 50 of ripening to determine the effect of $\mathrm{HP}$ on the inactivation of naturally occurring microorganisms and on the microbiological quality and safety of ripe cheese.

Two batches of La Serena cheese were made, each from $400 \mathrm{~L}$ of refrigerated Merino ewes' raw milk with no added starter cultures and at the same dairy on different days. Milk was coagulated at $30^{\circ} \mathrm{C}$ for 75 min with an aqueous extract of macerated C. cardunculus flowers. Curds were cut into 20 -mm cubes, held at $30^{\circ} \mathrm{C}$ for 15 min, and distributed into cylindrical molds. Milk and curd samples were transported to the laboratory at $4^{\circ} \mathrm{C}$ and analyzed on the day of manufacture.

Cheeses, 18-cm diameter and 6-cm high, were pressed for $6 \mathrm{~h}$ and salted by rubbing dry salt twice on the surface. They were ripened at the dairy for $60 \mathrm{~d}$ at $8^{\circ} \mathrm{C}$ and $90 \%$ relative humidity. The effect of HP treatments at 300 and $400 \mathrm{MPa}$ on $\mathrm{d} 2$ and 50 were compared to select the most effective treatment. Six cheeses from each batch 
were vacuum-packed in CN300 bags (Cryovac Grace S. A., Barcelona, Spain) on d 2 and HP-treated; 3 were HPtreated at $300 \mathrm{MPa}$, and 3 were $\mathrm{HP}$-treated at $400 \mathrm{MPa}$ for $10 \mathrm{~min}$ at an initial temperature of $10^{\circ} \mathrm{C}$ by means of a 100-L capacity discontinuous isostatic press at NC Hyperbaric (Burgos, Spain). Times to reach 300 and 400 $\mathrm{MPa}$ were 4.5 and $5.9 \mathrm{~min}$, respectively, and depressurization times were 1.4 and $1.8 \mathrm{~min}$, respectively. Temperature of the water used as pressure-transmitting fluid did not exceed $14^{\circ} \mathrm{C}$ during the process. On d 50, two cheeses from each batch were vacuum-packed in CN300 bags and HP-treated, one at $300 \mathrm{MPa}$ and one at 400 $\mathrm{MPa}$, for $10 \mathrm{~min}$ at $10^{\circ} \mathrm{C}$. After HP treatments, cheeses were unpacked and followed ripening at $8^{\circ} \mathrm{C}$. Nonpressurized cheeses from each batch served as the control. After ripening for 3, 30, or $60 \mathrm{~d}$, cheeses were transported to the laboratory at $4^{\circ} \mathrm{C}$ and analyzed on the same day.

Representative curd or cheese samples (10 g) were homogenized with $90 \mathrm{~mL}$ of a sterile $2 \%$ (wt/vol) sodium citrate solution at $45^{\circ} \mathrm{C}$ in a Colworth Stomacher 400 (A. J. Seward Ltd., London, UK). Decimal dilutions of samples were prepared in sterile $0.1 \%$ peptone solution. Viable aerobic counts, lactic acid bacteria (LAB), lactobacilli, and enterococci were determined on duplicate plates of PCA (Biolife, Milano, Italy) incubated for $48 \mathrm{~h}$ at $30^{\circ} \mathrm{C}, \mathrm{MRS}$ agar (Biolife; acidified at $\mathrm{pH} 5.7$ with acetic acid) incubated for $48 \mathrm{~h}$ at $30^{\circ} \mathrm{C}$, Rogosa agar (Biolife) incubated anaerobically for $48 \mathrm{~h}$ at $37^{\circ} \mathrm{C}$, and KF Streptococcus agar (Oxoid, Basingstoke, UK) incubated for 48 $\mathrm{h}$ at $37^{\circ} \mathrm{C}$, respectively.

Micrococcaceae were determined on duplicate plates of MSA (Oxoid) incubated for $72 \mathrm{~h}$ at $30^{\circ} \mathrm{C}$. Coagulasepositive staphylococci were determined on duplicate plates of Baird-Parker agar (Oxoid) with RPF Supplement II (Biolife) incubated at $37^{\circ} \mathrm{C}$ for $48 \mathrm{~h}$ and, if necessary, enrichment of 1-g cheese samples was carried out as previously described (Arqués et al., 2005a). For detecting the presence of $L$. monocytogenes, $25 \mathrm{~mL}$ of milk and $25 \mathrm{~g}$ of curd or cheese samples were enriched as previously described (Arqués et al., 2005b). Gram-negative bacteria (GNB) and coliforms were determined on duplicate plates of PMK agar (Biolife) incubated for 24 $\mathrm{h}$ at $30^{\circ} \mathrm{C}$ and VRBA agar (Oxoid) incubated for $24 \mathrm{~h}$ at $37^{\circ} \mathrm{C}$, respectively. Enrichment for E. coli O157:H7 detection in $25 \mathrm{~mL}$ of milk and $25 \mathrm{~g}$ of curd or cheese samples was carried out as previously described (Rodríguez et al., 2005).

Cheese $\mathrm{pH}$ was measured in duplicate directly with a Crison penetration electrode (model 52-3,2, Crison Instruments S. A., Barcelona, Spain) by means of a Crison GPL $22 \mathrm{pH}$ meter.

Analysis of variance with HP treatment, cheese age, and experiment as main effects was performed on analytical variables by means of SPSS Win 8.0 program.
Table 1. Counts $^{1}$ (log cfu/g) of the main microbial groups in milk and curd during manufacture of La Serena cheese

\begin{tabular}{lll}
\hline & Milk & Curd \\
\hline Viable aerobic counts & $6.81 \pm 0.03$ & $7.45 \pm 0.05$ \\
Lactic acid bacteria & $6.07 \pm 0.08$ & $7.06 \pm 0.12$ \\
Lactobacilli & $5.45 \pm 0.02$ & $5.96 \pm 0.09$ \\
Enterococci & $5.62 \pm 0.07$ & $6.69 \pm 0.02$ \\
Micrococcaceae & $4.23 \pm 0.06$ & $4.17 \pm 0.06$ \\
Coagulase + staphylococci & $2.39 \pm 0.44$ & $3.03 \pm 0.20$ \\
Gram-negative bacteria & $6.72 \pm 0.05$ & $7.37 \pm 0.03$ \\
Coliforms & $6.18 \pm 0.07$ & $6.59 \pm 0.01$ \\
Escherichia coli O157:H7 & $\mathrm{ND}^{2}$ & $\mathrm{ND}$ \\
Listeria monocytogenes & $\mathrm{ND}^{2}$ & $\mathrm{ND}$ \\
\hline
\end{tabular}

${ }^{1}$ Mean \pm SD of duplicate determinations on 2 experiments.

${ }^{2} \mathrm{ND}=$ Not detected by enrichment of $25-\mathrm{mL}$ or 25 -g samples.

Comparison of means at $P<0.05$ by Tukey's test was carried out using the same program.

Counts of microbial groups in milk were generally high (Table 1), which is in agreement with levels previously reported for Merino ewes' raw milk (Fernández del Pozo et al., 1988). The GNB was the predominant group in milk at levels that were 0.65 log units higher than LAB. Lactobacilli, enterococci, and coagulase-positive staphylococci counts in milk were similar to those previously reported (Fernández del Pozo et al., 1988), but coliform counts were $2.1 \mathrm{log}$ units higher, indicating unhygienic milking practices. Growth of most microbial groups during milk coagulation and whey drainage (from milk to curd) was scarce (Table 1). Higher increases from milk to curd, ranging from 0.8 to $2.3 \mathrm{log}$ units, had been previously reported for the different microbial groups during manufacture of La Serena cheese (Fernández del Pozo et al., 1988).

From curd to 3-d-old control cheese, levels of all microbial groups increased (Table 2), but during the rest of the ripening period, all groups declined with the exception of lactobacilli. Listeria monocytogenes, and E. coli $\mathrm{O} 157: \mathrm{H} 7$ were absent from all cheese samples throughout ripening.

Milk and curd mean $\mathrm{pH}$ values were 6.61 and 6.52, respectively (data not shown). On d $3, \mathrm{pH}$ of control cheese was still 5.73 (Table 2), revealing a slow acid production by LAB as previously reported for this cheese variety (Fernández del Pozo et al., 1988). The HP treatment and cheese age influenced $\mathrm{pH}$ value significantly $(P<0.05)$, which decreased with age in treated and control cheeses. Cheeses treated on d 2 at 300 and 400 $\mathrm{MPa}$ showed $\mathrm{pH}$ values that were 0.27 and 0.39 units higher, respectively, on $d 3$ than the control cheese (Table 2).

Viable aerobic counts were significantly $(P<0.05)$ influenced by HP treatments on d 2, decreasing to levels that were 0.99 and $2.02 \log$ units lower on $\mathrm{d} 3$ in cheeses treated at 300 and $400 \mathrm{MPa}$, respectively, compared with 
Table 2. Cheese $\mathrm{pH}$ values and counts (log cfu/g) of the main microbial groups during ripening of La Serena cheeses that were high pressure (HP)-treated on d 2 or 50 at 300 or $400 \mathrm{MPa}$ for $10 \mathrm{~min}^{1}$

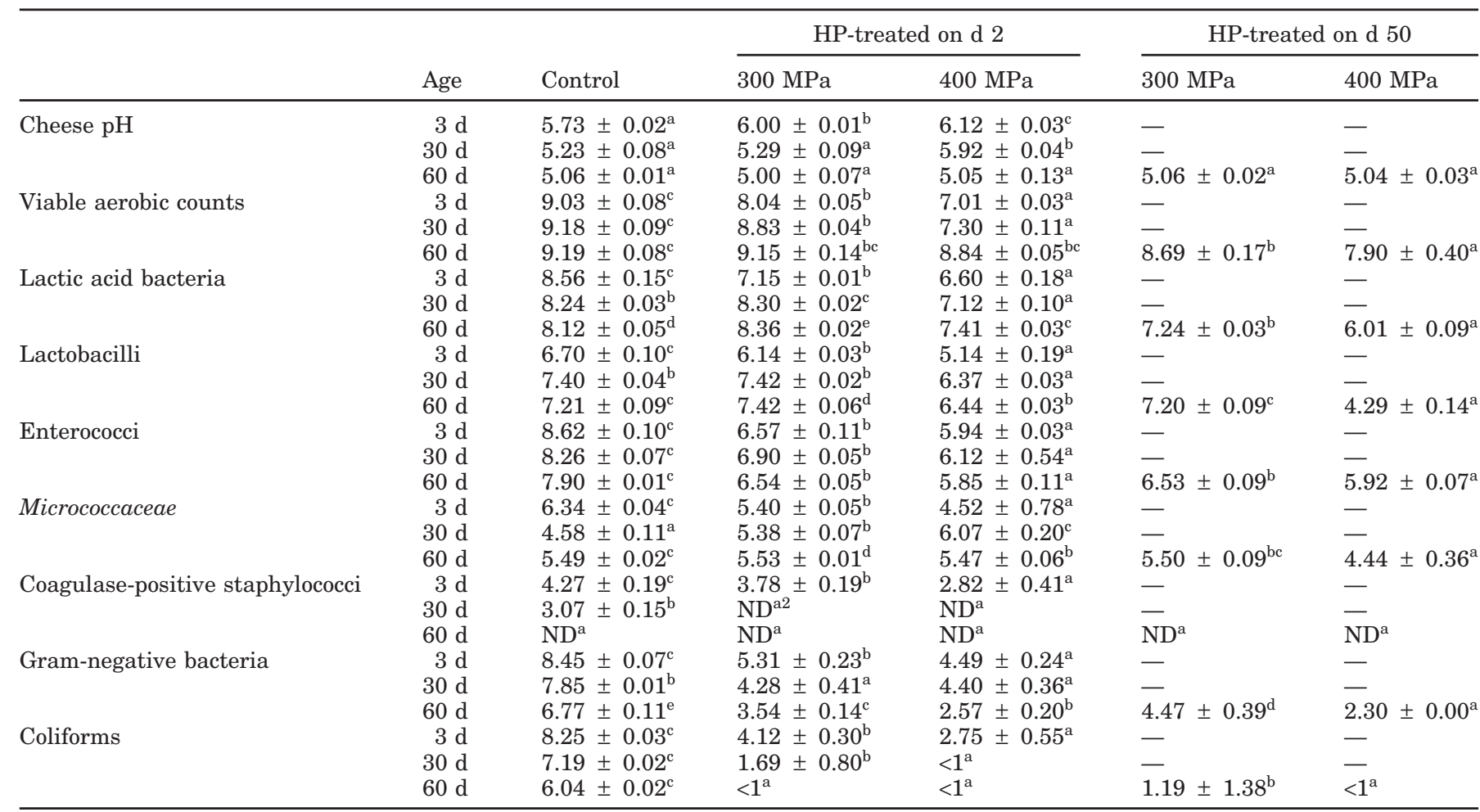

${ }^{\mathrm{a}-\mathrm{e}}$ Means in the same row with the same superscript do not differ significantly at $P<0.05$.

${ }^{1}$ Mean $\pm \mathrm{SD}$ of duplicate determinations on 2 experiments.

${ }^{2} \mathrm{ND}=$ Not detected by enrichment of 1-g samples.

the control cheese (Table 2). Treatments at 300 and 400 $\mathrm{MPa}$ on $\mathrm{d} 50$ resulted in viable aerobic counts that were 0.50 and $1.29 \mathrm{log}$ units lower on d 60 than in control cheese. Reductions of 2 and 5 log units were reported for total bacterial counts in cheeses from 1-d-old ewes' milk treated at 300 and $400 \mathrm{MPa}$, respectively, for 10 min at $12^{\circ} \mathrm{C}$ (Juan et al., 2004).

Lactic acid bacteria, lactobacilli, and enterococci counts in cheese treated on d 2 at $300 \mathrm{MPa}$ were 1.41 , 0.56 , and $2.05 \log$ units lower, respectively, on d 3 compared with control cheese, whereas in cheese treated at $400 \mathrm{MPa}$, these same differences were $1.96,1.56$, and 2.68 log units, respectively (Table 2). Lactobacilli have been shown to be more resistant to HP treatments than lactococci (Casal and Gómez, 1999). In cheeses treated with HP on $\mathrm{d} 2$, populations of LAB and lactobacilli recovered from d 3 to 30 , whereas enterococci counts remained fairly constant throughout ripening. When HP treatments were applied on d 50, counts of LAB, lactobacilli, and enterococci on d 60 were $0.88,0.01$, and 1.29 log units lower in 300-MPa cheese and 2.11, 2.92, and $1.98 \mathrm{log}$ units lower in $400-\mathrm{MPa}$ cheese, respectively, than in control cheese. Reductions of 1 to $2 \log$ units were reported for 4 Lactococcus lactis strains in Cheddar cheese treated at $300 \mathrm{MPa}$ for $20 \mathrm{~min}$ at $25^{\circ} \mathrm{C}$, and reductions of 2 to $5 \log$ units were reported when treated Cheddar cheese was treated at $400 \mathrm{MPa}$ (O'Reilly et al., 2002). Treatment of Swiss cheese slurries at 345 and $550 \mathrm{MPa}$ for $10 \mathrm{~min}$ at $25^{\circ} \mathrm{C}$ reduced lactococci counts by 1 and $6 \log$ units, respectively, and reduced lactobacilli counts by 1 and 3 log units (Jin and Harper, 2003). In cheese from ewes' milk that was treated at 300 and 400 $\mathrm{MPa}$ for $10 \mathrm{~min}$ at $12^{\circ} \mathrm{C}$, LAB counts were lowered by 0.5 and $5 \log$ units, respectively, and lactobacilli counts were lowered by 1 and $2 \log$ units (Juan et al., 2004). In Cheddar cheese, treatments at 300 and $400 \mathrm{MPa}$ for 5 min at $25^{\circ} \mathrm{C}$ reduced L. lactis counts by 1.0 and $4.7 \mathrm{log}$ units, respectively, and reduced lactobacilli counts by 2 and 5 log units (Wick et al., 2004).

High-pressure treatment on $\mathrm{d} 2$ at $300 \mathrm{MPa}$ lowered counts of Micrococcaceae and coagulase-positive staphylococci on $\mathrm{d} 3$ by 0.94 and $0.49 \mathrm{log}$ units compared with control cheese, and treatment at $400 \mathrm{MPa}$ lowered counts by 1.82 and 1.45 log units, respectively (Table 2). Coagulase-positive staphylococci were not detected on d 30 in cheeses treated at 300 or $400 \mathrm{MPa}$ on d 2 but reached counts of $3.07 \mathrm{log}$ units in control cheese. Staphylococcus aureus counts were reduced by 3 log units in 
Cheddar cheese treated at $400 \mathrm{MPa}$ for $20 \mathrm{~min}$ at $20^{\circ} \mathrm{C}$ (O'Reilly et al., 2000) and were reduced by $>3$ log units in Swiss cheese slurries treated at 345 or $550 \mathrm{MPa}$ for $10 \mathrm{~min}$ at $25^{\circ} \mathrm{C}$ (Jin and Harper, 2003). Also, reductions of 0.45 and $2.43 \mathrm{log}$ units in Staph. aureus counts were achieved in raw milk cheese treated at 300 and $500 \mathrm{MPa}$, respectively, for $10 \mathrm{~min}$ at $10^{\circ} \mathrm{C}$ on $\mathrm{d} 2$ compared with 3-d-old control cheese (Arqués et al., 2005a).

Gram-negative bacteria, in particular coliforms, were more sensitive to HP treatment than gram-positive bacteria (Table 2). The GNB and coliform counts in cheese treated on d 2 at $300 \mathrm{MPa}$ were 3.14 and 4.13 log units lower, respectively, on d 3 compared with the control cheese, and in cheese treated at $400 \mathrm{MPa}$, counts were 3.96 and $5.55 \mathrm{log}$ units lower (Table 2). Afterward, GNB counts decreased in all cheeses from d 3 to 60 by approximately 2 log units. Coliform counts decreased more rapidly during ripening in cheeses treated by $\mathrm{HP}$ on $\mathrm{d} 2$ than in control cheese and were below 1 log unit on $d$ 60 (Table 2). The HP treatment on d 50 also achieved coliform counts in 60-d-old cheeses that were close to or below $1 \log$ unit. Counts of $E$. coli were lowered by $>7$ log units in Mató cheese treated at $400 \mathrm{MPa}$ for $15 \mathrm{~min}$ at $10^{\circ} \mathrm{C}$ (Capellas et al., 1996) and in Cheddar cheese treated at $400 \mathrm{MPa}$ for $20 \mathrm{~min}$ at $20^{\circ} \mathrm{C}$ (O'Reilly et al., 2000). Treatments at 300 and $400 \mathrm{MPa}$ for $10 \mathrm{~min}$ at $12^{\circ} \mathrm{C}$ applied to ewe milk cheese resulted in a reduction of Enterobacteriaceae counts that were $>3$ log units (Juan et al., 2004). Reductions of 1.30 and $3.73 \mathrm{log}$ units were recorded for $E$. coli O157:H7 counts in raw milk cheese treated at $300 \mathrm{MPa}$ for $10 \mathrm{~min}$ at $10^{\circ} \mathrm{C}$ or $500 \mathrm{MPa}$ for $5 \mathrm{~min}$ at $10^{\circ} \mathrm{C}$, respectively (Rodríguez et al., 2005).

It may be concluded from our results that even a mild HP treatment of La Serena cheese, such as $300 \mathrm{MPa}$ for $10 \mathrm{~min}$, on $\mathrm{d} 2$ of ripening was effective in significantly reducing counts of undesirable contaminating microorganisms such as enterococci, coagulase-positive staphylococci, GNB, and coliforms in 3-d-old cheese and eliminated Staph. aureus and most coliforms in 30-d-old cheese. Higher reductions in microbial counts were achieved when 2-d-old cheese was treated at $400 \mathrm{MPa}$ for $10 \mathrm{~min}$. Although the efficacy of HP treatments on d 50 for the reduction of microbial contaminants was similar to that on d 2, early inactivation of Staph. aureus by HP treatment on $\mathrm{d} 2$ offered the additional advantage of reducing risks of staphylococcal enterotoxin production during cheese ripening. High-pressure treatment on d 2 at 300 to $400 \mathrm{MPa}$ for $10 \mathrm{~min}$ was a useful tool to improve significantly the microbiological quality and safety of ripe La Serena cheese.

\section{ACKNOWLEDGMENTS}

This work was supported by INIA project CAL 00-005. The authors thank NC Hyperbaric for HP treatment of cheeses and J. Tomillo and M. de Paz for their valuable technical assistance.

\section{REFERENCES}

Arqués, J. L., E. Rodríguez, P. Gaya, M. Medina, B. Guamis, and M. Nuñez. 2005a. Inactivation of Staphylococcus aureus in raw milk cheese by combinations of high pressure treatments and bacteriocin-producing lactic acid bacteria. J. Appl. Microbiol. 98:254-260.

Arqués, J. L., E. Rodríguez, P. Gaya, M. Medina, and M. Nuñez. 2005b. Effect of combinations of high pressure treatments and bacteriocinproducing lactic acid bacteria on the survival of Listeria monocytogenes in raw milk cheese. Int. Dairy J. 15:893-900.

Capellas, M., M. Mor-Mur, E. Sendra, R. Pla, and B. Guamis. 1996. Populations of aerobic mesophiles and inoculated $E$. coli during storage of fresh goat's milk cheese treated with high pressure. J. Food Prot. 59:582-587.

Carminati, D., M. Gatti, B. Bonvini, E. Neviani, and G. Mucchetti. 2004. High-pressure processing of Gorgonzola cheese: Influence on Listeria monocytogenes inactivation and on sensory characteristics. J. Food Prot. 67:1671-1675.

Casal, V., and R. Gómez. 1999. Effect of high pressure on the viability and enzymatic acitivity of mesophilic lactic acid bacteria isolated from caprine cheese. J. Dairy Sci. 82:1092-1097.

Farkas, D. F., and D. G. Hoover. 2000. High pressure processing. J. Food Sci. 65:47-64.

Fernández del Pozo, B., P. Gaya, M. Medina, M. A. Rodríguez-Marín, and M. Nuñez. 1988. Changes in the microflora of La Serena ewes' milk cheese during ripening. J. Dairy Res. 55:449-455.

Jin, Z. T., and W. J. Harper. 2003. Effect of high pressure (HP) treatment on microflora and ripening development in Swiss cheese slurries. Milchwissenschaft 58:134-137.

Juan, B., V. Ferragut, B. Guamis, M. Buffa, and A. J. Trujillo. 2004. Proteolysis of a high pressure-treated ewe's milk cheese. Milchwissenschaft 59:616-619.

O'Reilly, C. E., P. M. O'Connor, A. L. Kelly, T. P. Beresford, and P. M. Murphy. 2000. Use of hydrostatic pressure for inactivation of microbial contaminants in cheese. Appl. Environ. Microbiol. 66:4890-4896.

O'Reilly, C. E., P. M. O'Connor, P. M. Murphy, A. L. Kelly, and T. P. Beresford. 2002. Effects of high-pressure treatment on viability and autolysis of starter bacteria and proteolysis in Cheddar cheese. Int. Dairy J. 12:915-922.

Rodríguez, E., J. L. Arqués, M. Nuñez, P. Gaya, and M. Medina. 2005. Combined effect of high pressure treatments and bacteriocin-producing lactic acid bacteria on the inactivation of Escherichia coli O157:H7 in raw milk cheese. Appl. Environ. Microbiol. 71:33993404.

Sánchez-Rey, R., B. Poullet, P. Caceres, and G. Larriba. 1993. Microbiological quality and incidence of some pathogenic microorganisms in La Serena cheese throughout ripening. J. Food Prot. 56:879-881.

Smelt, J. P. P. 1998. Recent advances in the microbiology of high pressure processing. Trends Food Sci. Technol. 9:152-158.

Trujillo, A. J., M. Capellas, J. Saldo, R. Gervilla, and B. Guamis. 2002. Applications of high hydrostatic pressure on milk and dairy products: A review. Innov. Food Sci. Emerg. Technol. 3:295-307.

Wick, C., U. Nienaber, O. Anggraeni, T. H. Shellhammer, and P. D. Courtney. 2004. Texture, proteolysis and viable lactic acid bacteria in commercial Cheddar cheeses treated with high pressure. J. Dairy Res. 71:107-115. 